\title{
ESTIMATES OF VARIANCE COMPONENTS AND HERITABILITIES OF PRE- WEANING GROWTH TRAITS OF ANGLO-NUBIAN AND BALADI KIDS
}

\author{
M.H. Hammoud and M.M.I. Salem
}

Department of Animal and Fish Production, Faculty of Agriculture, Alexandria University, PC: 21545, Alexandria, Egypt

Received: $16 / 6 / 2019$

Accepted:14/7/2019

\section{SUMMARY}

Data relevant to 573 Anglo-Nubian and 318 Baladi kids born at Alexandria University Experimental Station between 1997-2014 were utilized in this investigation to estimate variance components and heritabilities of birth weight $(B W)$, weaning weight $(W W)$ and average daily gain $(A D G)$. In addition, effects of season and year of birth, sex of kid, type of birth and parity on the previous studied traits were investigated.

The least squares analysis with unequal subclass numbers showed that the overall means of $B W, W W$ and ADG of Anglo-Nubian kids were $2.55 \mathrm{~kg}, 13.18 \mathrm{~kg}$ and $87.14 \mathrm{~g}$, respectively, whereas they were for Baladi kids $2.25 \mathrm{~kg}, 10.19 \mathrm{~kg}$ and $64.74 \mathrm{~g}$, respectively. On the other hand, the statistical analyses showed that fixed effects on all studied traits were generally significant $(P<0.01$ or $P<0.05)$, except for effects of season of birth on $B W$ of Baladi and WW of Anglo-Nubian kids, and effects of parity on WW and ADG of Baladi breed.

Estimates of the direct heritability $\left(h^{2}\right)$ and maternal heritability $\left(h^{2}{ }_{m}\right)$ ranged from 0.36-0.58 and 0.05-0.30, from 0.01-0.38 and 0-0.18 and from 0.08-0.46 and 0-0.17 for BW, WW and ADG of Anglo-Nubian kids, respectively. The corresponding values for Baladi Kids ranged from 0.26-0.45 and 0.12-0.29, from 0.28-0.39 and 0.03-0.19 and from 0.21-0.31 and 0.03-0.18, respectively. Furthermore, estimates of the total heritability $\left(h_{t}^{2}\right)$ were moderate to high for BW in both breeds, and low to moderate for WW and ADG of Anglo-Nubian, and moderate for $W W$ and $A D G$ of Baladi breed. Estimates of the total maternal effects $\left(t_{m}\right)$ were considerable for all the studied traits of both breeds. The results in general showed that maternal effects were significant source of variation for pre-weaning growth traits of Anglo-Nubian and Baladi kids. Therefore, these effects should be taken into consideration when carrying out genetic evaluations of pre-weaning growth traits of both Anglo-Nubian and Baladi kids in their herd.

Keywords: Variance components, heritability, maternal effects, pre-weaning growth, Anglo-Nubian, Baladi, kids

\section{INTRODUCTION}

Goats' population in Egypt was 4350000 heads in 2013, and they contribute about $5.34 \%$ of the national total red meat production and about $3.56 \%$ of total milk production (FAO, 2015). They have good potential as a meat producing farm animal, especially when their reproductive and productive efficiencies are considered. Pre-weaning growth traits of kids are important in determining profitability of any goat production enterprise (Boujenane and El Hazzab 2008, Supakorn and Pralomkarn 2009, Zhang et al. 2009, Gowane et al. 2011, Mohammadi et al. 2012, Bazzi 2013 and Gupta et al. 2016).

Pre-weaning growth traits of goats are determined not only by the kid's genetic potential for growth, but also by the maternal genetic effects and environmental factors (Supakorn and Pralomkarn 2009, Zhang et al. 2009, Assan 2013 and Gupta et al. 2016). Many researchers found that pre-weaning growth traits of kids were most affected by maternal effects (Boujenane and El Hazzab 2008, Rashidi et al. 2008, Zhang et al. 2009, Supakorn and Pralomkarn 2009, Gholizadeh et al. 2010, Gowane et al. 2011, Mohammadi, et al. 2012 and Sadegh et al. 2013). Therefore, when these traits are included in the breeding programs, both the direct and maternal component should be taken into consideration in order to achieve an optimum progress from the selection (Boujenane and El Hazzab 2008, Rashidi et al. 2008, Gholizadeh et al. 2010, Osman 2013 and Rout et al. 2018).

This investigation was carried out to estimate variance components and heritabilities (direct and maternal) of birth weight, weaning weight and average daily gain from birth to weaning of Anglo-Nubian and Baladi kids in an experimental herd of goats.

\section{MATERIALS AND METHODS}

\section{Source of data:}

Data used for this study were collected from the records of the goats' herd of the Experimental Station, Faculty of Agriculture, Alexandria University. The records covered the period from 1997 to 2014 and included 573 and 318 Anglo-Nubian and Baladi kids presenting 20 and 18 sires and 125 and 84 dams, respectively. The structures of data are found in Table (1). 
Table 1: Means, standard deviations (SD), coefficient of variation (CV \%) and distribution of the data for birth weight (BW), weaning weight (WW) and average daily gain (ADG) of Anglo-Nubian and Baladi kids.

\begin{tabular}{lcccccc}
\hline \multicolumn{1}{c}{ Items } & \multicolumn{3}{c}{ Anglo-Nubian } & \multicolumn{3}{c}{ Baladi } \\
\cline { 2 - 6 } & BW & WW & ADG & BW & WW & ADG \\
\hline Mean, (kg or gm) & 2.55 & 13.18. & 87.14 & 2.25 & 10.19 & 64.74 \\
SD, (kg or gm) & 0.54 & 3.43 & 27.42 & 0.43 & 2.59 & 19.56 \\
CV (\%) & 21.18 & 26.02 & 31.47 & 19.11 & 25.42 & 30.21 \\
No. of records & 573 & 446 & 446 & 318 & 266 & 266 \\
No. of sires & 20 & 19 & 19 & 18 & 17 & 17 \\
No. of dams & 125 & 90 & 90 & 84 & 79 & 79 \\
No. of buck kids & 279 & 215 & 215 & 159 & 127 & 127 \\
No. of doe kids & 294 & 231 & 231 & 159 & 139 & 139 \\
No. of single kids & 128 & 100 & 100 & 95 & 81 & 81 \\
No. of twin kids & 374 & 290 & 290 & 205 & 170 & 170 \\
No. of triplet kids & 71 & 56 & 56 & 18 & 15 & 15 \\
\hline
\end{tabular}

Flock management:

Animals were housed in semi closed pens, fed on Berseem (Trifolium alexandrinum) during winter and spring and on stubble and Berseem hay and/or fodder sorghum (Sorghum bicolor) during summer and autumn. Supplementary concentrate ration of about $0.25 \mathrm{~kg} /$ head was offered daily along the year.

Kidding of the herd was managed all year around. Females were first mated at about 18 months of age. Sires and dams were selected as yearlings on the basis of visual appraisal for type and size rather than on a pre-set intensive selection programme. Once the doe entered the breeding flock, there is no chance for culling until the end of its productive life.

\section{Statistical procedures:}

Least squares of GLM procedure (SAS 2008) were utilize to test the significance of the fixed effects of season of birth (4 seasons), year of birth (6 periods), sex (male and female), type of birth (single, twin and triplet) and parity (7 parities) on birth weight (BW), weaning weight (WW) and average daily gain (ADG) from birth to weaning of kids. Months of birth were classified by season into autumn births between September and November, winter births between December and February, spring births between March and May and summer births between June and August. Years of birth from 1997-2014 were classified to six periods $(1=1997-1999,2=2000-2002,3=2003$ 2005, 4= 2006-2008, 5= 2009-2011 and 6= 20122014). Parity was between 1 and 6 or over. Each breed data were analyzed separately. The statistical model fitted was:

$\mathbf{Y}_{\mathrm{ijklmn}}=\mathrm{u}+\mathbf{A}_{\mathrm{i}}+\mathbf{B}_{\mathbf{j}}+\mathbf{C}_{\mathbf{k}}+\mathbf{D}_{\mathbf{l}}+\mathbf{P}_{\mathbf{m}}+\mathbf{e}_{\mathrm{ijklmn}}$ where, $\mathbf{Y}_{\mathbf{i j k l m n}}$ : either $\mathrm{BW}, \mathrm{WW}$ or $\mathrm{ADG}$ traits; $\boldsymbol{\mu}$ : an underlying constant specific to each trait; $\mathrm{A}_{\mathrm{i}}$ : the fixed effect of $i^{\text {th }}$ season of birth ( $i=1,2,3$ and 4$) ; \mathbf{B}_{\mathbf{j}}$ : the fixed effect of $\mathrm{j}^{\text {th }}$ year of birth $(\mathrm{j}=1,2,3 \ldots \ldots 6) ; \mathbf{C}_{\mathbf{k}}$ : the fixed effect of $k^{\text {th }} \operatorname{sex}\left(k=1\right.$ and 2); $\mathbf{D}_{\mathbf{l}}$ : the fixed effect of $1^{\text {th }}$ type of birth $(1=1$ and 2$) ; \mathrm{P}_{\mathrm{m}}$ : the fixed effect of $m^{\text {th }}$ parity $(m=1,2,3 \ldots . .6)$ and $\mathbf{e}_{\mathbf{i j k l m n}}$ : random residual assumed to be independent normally distributed with mean zero and variance $\sigma_{e}^{2}$.

Univariate animal models were fitted to estimate (co)variance components and heritabilities for each trait using Wombat program (Meyer, 2006). The following four models were used:

$y=X b+Z_{a} a+e$
$y=X b+Z_{a} a+Z_{c} c+e$
$y=X b+Z_{a} a+Z_{m} m+e$
$y=X b+Z_{a} a+Z_{m} m+Z_{c} c+e$

where $\mathrm{y}$ is a $\mathrm{n} \times 1$ vector of observations for each trait; b, a, m, c and e are vectors of fixed effects (season of birth, year of birth, sex, type of birth and parity), direct additive genetic effects, maternal additive genetic effects, maternal permanent environmental effects and the residual effects, respectively; $\mathrm{X}, \mathrm{Za}, \mathrm{Zm}, \mathrm{Zc}$ are the incidence matrices of fixed effects, direct additive genetic effects, maternal genetic effects and maternal permanent environmental effect; $A$ is the numerator relationship matrix between animals; and $\sigma_{\mathrm{am}}$ is the covariance between additive direct and maternal genetic effects. The (co)variance structure for the model was:

$\mathrm{V}(\mathrm{a})=\mathrm{A} \sigma_{\mathrm{a}}^{2}, \mathrm{~V}(\mathrm{~m})=\mathrm{A} \sigma_{\mathrm{m}}^{2}, \mathrm{~V}(\mathrm{c})=\mathrm{I}_{\mathrm{P}} \sigma_{\mathrm{c}}^{2}, \mathrm{~V}(\mathrm{e})=\mathrm{I}_{\mathrm{R}}$ $\sigma^{2}$ and $\operatorname{Cov}(\mathrm{a}, \mathrm{m})=\mathrm{A} \sigma_{\mathrm{am}}$

where $I_{P}$ and $I_{R}$ are identity matrices with orders equal to the number of dams and the number of kids, respectively and $\sigma_{\mathrm{a}}^{2}, \sigma_{\mathrm{m}}^{2}, \sigma_{\mathrm{c}}^{2}$, and $\sigma_{\mathrm{e}}^{2}$ are direct additive genetic variance, maternal additive genetic variance, maternal permanent environmental variance, and residual variance, respectively. 
Estimates of direct heritability $\left(\mathrm{h}^{2}{ }_{\mathrm{a}}\right)$, maternal heritability $\left(\mathrm{h}_{\mathrm{m}}^{2}\right)$ and permanent maternal environmental effects $\left(c^{2}\right)$ were calculated as ratios of estimates of $\sigma_{\mathrm{a}}^{2}, \sigma_{\mathrm{m}}^{2}$, and $\sigma_{\mathrm{c}}^{2}$, respectively, to the phenotypic variance $\sigma_{p}^{2}$ ). The direct-maternal correlation $\left(\mathrm{r}_{\mathrm{am}}\right)$ was computed as the ratio of the estimates of direct-maternal covariance $\left(\sigma_{\mathrm{am}}\right)$ to the product of the square roots of estimates of $\sigma^{2}$ and $\sigma_{\mathrm{m}}^{2}$. The total heritability for each trait was estimated (Willham, 1972) as $\mathrm{h}_{\mathrm{t}}^{2}=\mathrm{h}_{\mathrm{a}}^{2}+0.5 \mathrm{~h}_{\mathrm{m}}^{2}+1.5 \mathrm{~h}_{\mathrm{m}} \mathrm{r}_{\mathrm{am}} \mathrm{h}_{\mathrm{a}}$, which predicts the expected response to phenotypic selection. The total maternal effect, $t_{m}=1 / 4 h^{2}{ }_{a}+h^{2}{ }_{m}$ $+c^{2}+h_{m} r_{a m} h_{a}$ was calculated to estimate repeatability of doe performance.

\section{RESULTS AND DISCUSSION}

The means, standard deviation (SD) and coefficient of variation (CV \%) of the studied traits are shown in Table 1.The overall means of BW, WW and ADG of Anglo-Nubian kids were $2.55 \mathrm{~kg}, 13.18$ $\mathrm{kg}$ and $87.14 \mathrm{~g}$, respectively, their corresponding values for Baladi kids were $2.25 \mathrm{~kg}, 10.19 \mathrm{~kg}$ and $64.74 \mathrm{~g}$, respectively. Although Anglo-Nubian breed had more twin and triplet births, higher BW means of kids of that breed were attained. Anglo-Nubian does are larger in size and BW of their kids was slightly higher than that of Baladi with differences remaining consistent for WW. High ADG of Anglo-Nubian reflects the genetic potential of the kids and the mothering ability of the does and caused an increase in WW of Anglo-Nubian kids over Baladi kids.

\section{Fixed effects:}

The results of analysis of variance in Table 2 show that fixed effects on all studied traits were generally significant $(\mathrm{P}<0.01$ or $\mathrm{P}<0.05)$ except for effects of season of birth on BW of Baladi and WW of Anglo-Nubian kids and effects of parity on WW and ADG of Baladi breed. Fixed effects on pre-weaning growth traits of kids of different goat breeds along with the world have been well depicted in the literature (Boujenane and El Hazzab 2008, Otuma and Osakwe 2008, Rashidi et al. 2008, Hermiz et al. 2009, Zhang et al. 2009, Mohammadi et al. 2012, Bedhane et al. 2013, Deribe and Taye 2013, Osman 2013, Bingol et al. 2014, Paul et al. 2014, Ray et al. 2015, Syahirah et al. 2016, Gupta et al. 2016 and Rout et al. 2018).

Table 2: Effects of season and year birth, sex of kid, type of birth and parity on birth weight (BW), weaning weight (WW) and pre-weaning average daily gain (ADG) of Anglo-Nubian and Baladi kids.

\begin{tabular}{lccccccc}
\hline \multirow{2}{*}{ Source of variation } & \multicolumn{4}{c}{ Anglo-Nubian } & \multicolumn{3}{c}{ Baladi } \\
\cline { 2 - 7 } & $\mathbf{d f}$ & BW & WW & ADG & BW & WW & ADG \\
\hline Season of birth & 3 & $* *$ & NS & $*$ & NS & $* *$ & $* *$ \\
Year of birth & 5 & $* *$ & $*$ & $*$ & $* *$ & $* *$ & $* *$ \\
Sex of kid & 1 & $* *$ & $* *$ & $* *$ & $* *$ & $* *$ & $* *$ \\
Type of birth & 2 & $* *$ & $* *$ & $* *$ & $* *$ & $* *$ & $* *$ \\
Parity & 5 & $* *$ & $* *$ & $* *$ & $* *$ & NS & NS \\
Error & & $\mathbf{( 5 5 6 )}$ & $\mathbf{( 4 2 9 )}$ & $\mathbf{( 4 2 9 )}$ & $\mathbf{( 3 0 1 )}$ & $\mathbf{( 2 4 9 )}$ & $\mathbf{( 2 4 9 )}$ \\
\hline
\end{tabular}

NS: Not significant $(\mathrm{P}>0.05) ; *$ : Significant $(\mathrm{P}<0.05) ; * *$ : Highly significant $(\mathrm{P}<0.01)$

Figures within parentheses are the degree of freedom (df) for error.

Variance components and heritabilities:

Estimates of variance components $\left(\sigma_{\mathrm{a}}^{2}, \sigma_{\mathrm{m}}^{2}, \sigma_{\mathrm{c}}^{2}\right.$, $\sigma_{e}^{2}$ and $\left.\sigma_{p}^{2}\right)$, heritabilities $\left(h^{2}{ }_{a}, h^{2}{ }_{m}\right.$ and $\left.h_{t}^{2}\right)$, fraction of variance due to maternal permanent environmental effects $\left(c^{2}\right)$, total maternal effect $\left(t_{m}\right)$ and loglikelihood ( $\log \mathrm{L}$ ) for BW, WW and ADG of AngloNubian and Baladi kids are shown in Table 3.

Model 1, which ignored the permanent environmental and additive maternal effects, had the lowest Log Likelihood values ( $\log$ L) for all studied traits of both Anglo-Nubian and Baladi kids. However, model 4 that included direct and maternal genetic and permanent environmental effects was the most appropriate model for BW of both breeds and for $\mathrm{WW}$ and $\mathrm{ADG}$ of Baladi and model 2 that included direct and maternal permanent environmental effects was the most appropriate model for WW and ADG of Anglo-Nubian. Hence, the genetic and permanent maternal environmental effects were important for BW of kids of both breeds and for WW and ADG of Baladi kids. For AngloNubian, model 2 was considered to be better than model 4 for WW and ADG, because the maternal genetic effects in model 4 were approximately zero. On the other hand, model 4 was the best model for WW and ADG of Baladi kids. Generally, the permanent environmental effect was determined to be more important than maternal additive effect for WW and ADG of kids of both breeds in this herd. 
Table 3: Estimates of variance components and genetic parameters for birth weight (BW), weaning weights (WW), and average daily gain (ADG) of Anglo-Nubian (A) and Baladi (B) and kids.

\begin{tabular}{|c|c|c|c|c|c|c|c|c|c|c|c|c|c|}
\hline Breed & Trait & Model & $\sigma_{\mathrm{a}}^{2}$ & $\sigma_{m}^{2}$ & $\sigma_{c}^{2}$ & $\sigma_{e}^{2}$ & $\sigma_{p}^{2}$ & $\mathbf{h}^{2}{ }_{\mathrm{a}}$ & $\mathbf{h}^{2}$ & $\mathrm{c}^{2}$ & $\mathbf{h}_{t}^{2}$ & $\mathbf{t}_{\mathrm{m}}$ & Log-I \\
\hline \multirow{12}{*}{$\mathbf{A}$} & & M1 & 0.19 & - & - & 0.14 & 0.34 & $0.58(0.11)$ & - & - & 0.58 & 0.14 & 13.31 \\
\hline & BW & M2 & 0.13 & - & 0.08 & 0.12 & 0.34 & $0.39(0.14)$ & - & $\begin{array}{c}0.24 \\
(0.07)\end{array}$ & 0.39 & 0.34 & 26.99 \\
\hline & & M3 & 0.13 & 0.12 & - & 0.13 & 0.37 & $0.36(0.14)$ & $\begin{array}{c}0.30 \\
(0.08)\end{array}$ & - & 0.51 & 0.39 & 24.56 \\
\hline & & M4 & 0.13 & 0.02 & 0.07 & 0.12 & 0.34 & $0.38(0.15)$ & $\begin{array}{c}0.05 \\
(0.10)\end{array}$ & $\begin{array}{c}0.20 \\
(0.09)\end{array}$ & 0.41 & 0.35 & 27.20 \\
\hline & & M1 & 4.81 & - & - & 7.83 & 12.7 & $0.38(0.14)$ & - & - & 0.38 & 0.10 & -772.26 \\
\hline & WW & M2 & 0.12 & - & 2.33 & 9.75 & 12.2 & $0.01(0.07)$ & - & $\begin{array}{c}0.19 \\
(0.06)\end{array}$ & 0.01 & 0.19 & -767.92 \\
\hline & & M3 & 0.24 & 2.21 & - & 9.76 & 12.2 & $0.02(0.08)$ & $\begin{array}{c}0.18 \\
(0.06)\end{array}$ & - & 0.11 & 0.19 & -768.65 \\
\hline & & M4 & 0.12 & 0.00 & 2.33 & 9.75 & 12.2 & $0.01(0.07)$ & $\begin{array}{l}0.000 \\
(0.40)\end{array}$ & $\begin{array}{c}0.19 \\
(0.39)\end{array}$ & 0.01 & 0.19 & -767.92 \\
\hline & & M1 & 38.4 & - & - & 446.3 & 827.8 & $0.46(0.14)$ & - & - & 0.46 & 0.12 & -1663.69 \\
\hline & ADG & M2 & 65.3 & - & 134.6 & 589.5 & 789.3 & $0.08(0.11)$ & - & $\begin{array}{c}0.17 \\
(0.07)\end{array}$ & 0.08 & 0.19 & -1660.73 \\
\hline & & M3 & 69.7 & 130.3 & - & 590.3 & 970.3 & $0.09(0.17)$ & $\begin{array}{c}0.17 \\
(0.07)\end{array}$ & - & 0.17 & 0.19 & -1661.13 \\
\hline & & M4 & 74.5 & 0.10 & 143.2 & 583.1 & 800.8 & $0.09(0.12)$ & $\begin{array}{c}0.00 \\
(0.47)\end{array}$ & $\begin{array}{c}0.18 \\
(0.47)\end{array}$ & 0.09 & 0.20 & -1660.75 \\
\hline \multirow{12}{*}{ B } & & M1 & 0.10 & - & - & 0.12 & 0.22 & $0.45(0.12)$ & - & - & 0.45 & 0.11 & 58.19 \\
\hline & BW & M2 & 0.06 & - & 0.05 & 0.10 & 0.22 & $0.29(0.14)$ & - & $\begin{array}{c}0.25 \\
(0.08)\end{array}$ & 0.26 & 0.32 & 65.81 \\
\hline & & M3 & 0.06 & 0.07 & - & 0.11 & 0.23 & $0.26(0.14)$ & $\begin{array}{c}0.29 \\
(0.09)\end{array}$ & - & 0.40 & 0.36 & 65.45 \\
\hline & & M4 & 0.06 & 0.03 & 0.03 & 0.10 & 0.22 & $0.27(0.14)$ & $\begin{array}{c}0.12 \\
(0.16)\end{array}$ & $\begin{array}{c}0.14 \\
(0.13)\end{array}$ & 0.33 & 0.33 & 66.08 \\
\hline & & M1 & 2.72 & - & - & 4.18 & 6.89 & $0.39(0.13)$ & - & - & 0.39 & 0.10 & -392.23 \\
\hline & WW & M2 & 2.27 & - & 1.07 & 3.65 & 6.99 & $0.32(0.15)$ & - & $\begin{array}{c}0.15 \\
(0.07)\end{array}$ & 0.32 & 0.24 & -388.79 \\
\hline & & M3 & 2.04 & 1.38 & - & 3.84 & 7.26 & $0.28(0.15)$ & $\begin{array}{c}0.19 \\
(0.09)\end{array}$ & - & 0.38 & 0.26 & -389.50 \\
\hline & & M4 & 2.22 & 0.24 & 0.91 & 3.66 & 7.03 & $0.32(0.16)$ & $\begin{array}{c}0.03 \\
(0.13)\end{array}$ & $\begin{array}{c}0.13 \\
(0.11)\end{array}$ & 0.33 & 0.24 & -388.75 \\
\hline & & M1 & 124. 2 & - & - & 282.6 & 406.8 & $0.31(0.13)$ & - & - & 0.31 & 0.08 & -922.84 \\
\hline & ADG & M2 & 94.7 & - & 64.2 & 251.7 & 410.6 & $0.23(0.14)$ & - & $\begin{array}{c}0.16 \\
(0.07)\end{array}$ & 0.23 & 0.21 & -919.46 \\
\hline & & M3 & 88.5 & 78.5 & - & 260.0 & 427.0 & $0.21(0.14)$ & $\begin{array}{c}0.18 \\
(0.09)\end{array}$ & - & 0.30 & 0.24 & -920.10 \\
\hline & & M4 & 94.0 & 12.6 & 54.8 & 251.5 & 413.0 & $0.23(0.15)$ & $\begin{array}{c}0.03 \\
(0.13)\end{array}$ & $\begin{array}{c}0.13 \\
(0.12)\end{array}$ & 0.24 & 0.22 & -919.43 \\
\hline
\end{tabular}

$\sigma_{\mathrm{a}}^{2}$ : direct additive genetic variance, $\sigma_{\mathrm{m}}^{2}$ : maternal genetic variance, $\sigma_{\mathrm{c}}^{2}$ : maternal permanent environmental variance, $\sigma_{\mathrm{e}}^{2}$ : residual variance, $\sigma_{\mathrm{p}}^{2}$ : phenotypic variance, $\mathrm{h}_{\mathrm{a}}{ }_{\mathrm{a}}$ : direct heritability, $\mathrm{h}_{\mathrm{m}}^{2}$ : maternal heritability, $\mathrm{c}^{2}$ : fraction of phenotypic variance due to maternal permanent environmental effects, $\mathrm{h}_{\mathrm{t}}^{2}$ : total heritability $\left(\mathrm{h}_{\mathrm{t}}^{2}=\mathrm{h}_{\mathrm{a}}^{2}+0.5 \mathrm{~h}_{\mathrm{m}}^{2}+1.5\right.$ $\left.\mathrm{mr}_{\mathrm{am}} \mathrm{h}\right), \mathrm{t}_{\mathrm{m}}$ : total maternal effect $\left(\mathrm{t}_{\mathrm{m}}=1 / 4 \mathrm{~h}_{\mathrm{a}}^{2}+\mathrm{h}_{\mathrm{m}}^{2}+\mathrm{c}^{2}+\mathrm{mr}_{\mathrm{am}} \mathrm{h}\right)$ and log-l: log- likelihood values. 
In addition, model 1 had the highest estimates of $\sigma^{2}{ }_{a}$ and $h^{2}$ for $\mathrm{BW}, \mathrm{WW}$ and ADG of both breeds. The addition of the maternal effects in the models reduced the values of both $\sigma^{2}$ and $h^{2}$ a compared to model 1 for all studied traits in both breeds. Several studies showed that including of the maternal effects in the models resulted in more accurate estimation of (co)variance and genetic parameters of growth traits of kids (Gholizadeh et al. 2010, Gowane et al. 2011 and Osman 2013 and Rout et al. 2018). The current estimates of $\mathrm{h}_{\mathrm{a}}^{2}$ and $\mathrm{h}_{\mathrm{m}}^{2}$ varied from 0.36-0.58 and $0.05-0.30$, from $0.01-0.38$ and $0-0.18$ and from 0.08 0.46 and $0-0.17$ for BW, WW and ADG of AngloNubian kids, respectively, the corresponding values for Baladi kids were varied from $0.26-0.45$ and $0.12-0.29$, from 0.28-0.39 and 0.03-0.19 and from 0.21-0.31 and $0.03-0.18$, respectively. These estimates of $\mathrm{h}^{2}$ and $\mathrm{h}^{2}{ }_{\mathrm{m}}$ for body weights showed a tendency to decrease with advanced in ages. This tendency has also been documented in several studies (Assan, 2013, Osman 2013 and Gupta et al. 2016). The moderate to high $\mathrm{h}_{\mathrm{a}}^{2}$ estimates obtained in this study for BW of both breeds indicated that direct genetic effects constitute a large portion of the phenotypic variances for this trait. The low $\mathrm{h}^{2}$ a estimates obtained in this study for WW and ADG of Anglo-Nubian kids except in model 1 indicated that direct genetic effects constitute a little portion of the phenotypic variances for these traits of this breed. Hence, slow genetic response would be expected through direct selection for these traits in Anglo-Nubian kids. This may be attributed to the low nutritional levels and the differences in managing practices at the goats breeding station, creating large environmental variations. However, moderate $\mathrm{h}^{2}$ estimates for $\mathrm{WW}$ and ADG of Baladi kids suggested that efforts could be made, thus, in bringing about improvement in these traits through selection, as well as managerial practices. The estimates of $\mathrm{h}_{\mathrm{m}}^{2}$ for BW were higher than for WW and ADG for Anglo-Nubian and Baladi kids. Hence, maternal additive effects constitute an important part of variation for BW of both breeds. The low $\mathrm{h}_{\mathrm{m}}^{2}$ estimates for WW and ADG of AngloNubian and Baladi kids in model 2 and very low in model 4 indicated that genetic effects constitute a little portion of the phenotypic variances for these traits of both breeds. Hence, the maternal genetic effect was determined to be lower important than permanent environmental effect for WW and ADG of Anglo-Nubian and Baladi kids in this herd.

The estimates of $\mathrm{h}_{\mathrm{a}}^{2}$ and $\mathrm{h}_{\mathrm{m}}^{2}$ in the literature were ranged from 0.04 to 0.54 and 0.04 to 0.33 for $\mathrm{BW}$, from 0.02 to 0.51 and 0 to 0.30 for $\mathrm{WW}$ and from 0.04 to 0.39 and 0.01 to 0.52 for ADG, respectively depending on the model used and the breed of kids (Shaat et al. 2007,Boujenane and El Hazzab2008, Kantanamalakul et al. 2008, McManus et al. 2008, Rashidi et al. 2008, Hermiz et al. 2009, Supakorn and Pralomkarn 2009, Zhang et al. 2009, Alade et al. 2010, Gholizadeh et al. 2010, Gowane et al. 2011, Mohammadi et al. 2012, Snyman2012, Bedhane et al.
2013, Osman 2013, Sadegh et al. 2013, Kuthu et al. 2017 and Rout et al. 2018). Hence, the current estimates of $\mathrm{h}^{2}$ and $\mathrm{h}_{\mathrm{m}}^{2}$ for all studied traits are generally in agreement with those reported in the literature on several breeds of goats.

The present estimates of $\left(\mathrm{c}^{2}\right)$ obtained from models 2 and 4 were relatively important for all studied traits for Anglo-Nubian and Baladi kids. The estimates of $\mathrm{c}^{2}$ were varied from 0.20-0.24, 0.19-0.19 and 0.17-0.18 for BW, WW and ADG of AngloNubian kids, respectively, the corresponding values for Baladi kids were varied from 0.14-0.25, 0.13-0.15 and $0.13-0.16$, respectively. These estimates indicated that maternal permanent environmental effects were a significant source of variation for pre-weaning growth traits of Anglo-Nubian and Baladi kids. Hence, maternal permanent environmental effects should be taken into consideration when carrying out strategies for long term selection programmes for both breeds. Estimates of $\mathrm{c}^{2}$ for all studied traits for Anglo-Nubian were relatively higher than those for Baladi kids. These estimates are in agreement with those documented in different goat breeds in many countries of the world by Boujenane and El Hazzab2008, Kantanamalakul et al. 2008, McManus et al. 2008, Rashidi et al. 2008, Gholizadeh et al. 2010, Gowane et al. 2011, Mohammadi et al., 2012, Snyman 2012, Bedhane et al. 2013, Osman 2013, Sadegh et al. 2013 and Rout et al. 2018. Maternal permanent environmental effects probably reflected differences in the uterine capacity of the does for growth of the fetus and the effect of multiple births.

The current estimates of the total heritability $\left(\mathrm{h}_{\mathrm{t}}^{2}\right)$ were ranged from 0.39-0.58, 0.01-0.38 and 0.08-0.46 for $\mathrm{BW}, \mathrm{WW}$ and $\mathrm{ADG}$ of Anglo-Nubian kids, respectively, the corresponding values for Baladi kids were ranged from $0.29-0.45,0.32-0.39$ and $0.23-0.31$, respectively. The estimates of $\mathrm{h}^{2}$ for $\mathrm{BW}$ and $\mathrm{WW}$ are generally in agreement with those $(0.22-0.35$ and $0.16-0.23)$ and those (0.08-0.32 and 0.05-0.23) estimated values for $\mathrm{BW}$ and WW reported by Rashidi et al. (2008) and Gholizadeh et al. (2010) in Markhoz and Raeini goats in Iran, respectively. Estimates of $\mathrm{h}_{\mathrm{t}}^{2}$ (0.21-0.39, 0.08-0.12 and 0.07-11, respectively) for $\mathrm{BW}, \mathrm{WW}$ and $\mathrm{ADG}$ were higher than those reported by Gowane et al. (2011) in Sirohi goat in India. Mohammadi et al. (2012) reported estimates of $\mathrm{h}_{\mathrm{t}}^{2}(0.17,0.30$ and 0.12$)$ for $\mathrm{BW}, \mathrm{WW}$ and ADG in Raeini Cashmere goats in Iran. Gowane et al. (2011) pointed out that the estimates of $\mathrm{h}_{\mathrm{t}}^{2}$ are model sensitive. When maternal effects are important in the expression of a trait, $\mathrm{h}_{\mathrm{t}}^{2}$ is of crucial importance in terms breeding and is useful in selection response based on phenotypic values.

Estimates of the total maternal effect $\left(t_{m}\right)$ obtained in this study were ranged from 0.14-0.39, 0.10-0.19 and 0.12- 0.20 for BW, WW and ADG of Anglo-Nubian kids, respectively, the corresponding values for Baladi kids were varied from $0.11-0.36,0.10-0.26$ and 0.08 0.24 , respectively. These estimates showed that maternal effects were a significant source of variation 
for pre-weaning growth traits of Anglo-Nubian and Baladi kids. Therefore, maternal effects should be considered when carrying out genetic evaluations of pre-weaning growth traits of kids of both breeds in this herd. Gowane et al. (2011) reported lower estimates of $\mathrm{t}_{\mathrm{m}}(0.10-0.18,0.03-0.10$ and $0.03-0.16)$ for BW, WW and ADG in Sirohi goat in India than the current findings.

\section{CONCLUSIONS}

The low genetic variations in WW and ADG of Anglo-Nubian kids proved that selection occurred in a slow genetic response. On the other side, the moderate genetic variations in $\mathrm{WW}$ and $\mathrm{ADG}$ of Baladi proved that selection resulted in a considerable genetic response. The results of this study showed the importance of inclusion of the maternal effects in the model of analysis, since the inclusion of these effects leads to more accurate estimation of variance component and heritabilities for pre-weaning growth traits of both breeds. Therefore, these effects should be taken into consideration when carrying out genetic selection strategies for long term breeding programs of pre-weaning growth traits for both Anglo-Nubian and Baladi kids in this flock.

\section{ACKNOWLEDGEMENT}

The authors are grateful to Mr. Ahmed Moustafa Mahmoud, the previous specialist of sheep and goats in the Experimental Station for his help in data availability.

\section{REFERENCES}

Alade, N.K., M.A. Dilala and A.O. Abdulyekeen, 2010. Phenotypic and genetic parameter estimates of litter size and body weights in goats. Int. J. Sci. Nat., 1: 262-266.

Assan, N., 2013. Various factors influencing birth weight in animal production. Scientific J. Rev., 7: 156-175.

Bazzi, H., 2013. Effects of environmental factors on growth curve variation for Kids 6-10 months old of Sistani goat. Int. J. Sci. Eng. Inv., 2: 36-39.

Bazzi, H. and M. Ghazaghi, 2011. Effects of Environmental factors on body weight of goats at different ages. J. Anim. and Vet. Advances, 10: 2819-2823.

Bedhane, M., A. Haile, H. Dadi and T. Alemu, 2013. Estimates of genetic and phenotypic parameter for growth traits in Arsi-Bale goat in Ethiopia. J. Anim. Sci. Adv., 9: 439-448.

Bingol, M., I. Daskiran and A. Yilmaz, 2014. A description of growth performances of Norduz kids and milk yield of Norduz goat. Bulgarian J. of Agri. Sci., 20: 690-698.

Boujenane, I. and A. El Hazzab, 2008. Genetic parameters for direct and maternal effects on body weights of Draa goats. Small Rumin. Res., $80: 16-21$.

Deribe, B. and M. Taye, 2013. Growth performance and carcass characteristics of central highland goats in Sekota District, Ethiopia. Sci. J. Agri. Adv., 2: 250-258.

FAO (2015). FAOSTAT Database Results, http: // www.fao.org.

Gholizadeh, M., G. Rahimi Mianji, M. Hashemi and H. Hafezian, 2010. Genetic parameter estimates for birth and weaning weights in Raeini goats. Czech J. Anim. Sci., 55: 30-36.

Gowane, G.R., A. Chopra and V. Prakash, 2011. Estimates of (co)variance components and genetic parameters for growth traits in Sirohi goat. Trop. Anim. Health Prod., 43: 189-198.

Gupta, J. P., D.P. Pandey and R.R. Shah, 2016. Genetic studies on growth traits of Mehsana goat of Gujarat, India. Indian J. Anim. Res., 50:164167.

Hermiz, H.N., J.E. Alkass, A.A. Hobi, and M.K. Asofi, 2009. Genetic and phenotypic parameter estimates of body weights in Iraqi local goat and their crosses with Damascus. The $2{ }^{\text {nd }}$ Kurdistan Conference on Biological Sciences. J. Duhok Univ. Vol. 12, No. 1 (Special Issue), Pp 189-194, 2009. Univ. Duhok 6-8 may, 2008.

Kantanamalakul, C., P. Sopannarath, M. Duangjinda, S. Anothaisinthawee and S. Tumwasorn, 2008. Genetic parameters for birth weight and weaning weight in Anglo-Nubian, Saanen, Thai Native and crossbred goats. Kasetsan J. (Nat. Sci.), 42: 640680.

Kuthu, Z. H., K. Javed, M. E. Babar, A. Sattar and M. Abdullah, 2017. Estimation of genetic parameters for pre-weaning growth traits in Teddy goats. J. Anim. Plant Sci., 27: 1408-1414.

McManus, C., G. S. Filho, H. Louvandini, L. T. Dias, R.D.A. Teixeira and E.L.S. Murata, 2008. Growth of Saanen, Alpine and Toggenburg goats in the Federal District, Brazil: Genetic and Environmental factors. Ciencia Anim. Bras., 9: 68-75.

Meyer, K., 2006. WOMBAT - Digging deep for quantitative genetic analyses by restricted maximum likelihood. Proc. $8^{\text {th }}$ World Congress of Genetics Applied for Livestock Production, Communication No. 27-14.17.

Mohammadi, H.; M.M. Shahrebabak and H.M. Shahrebabak, 2012. Genetic parameter estimates for growth traits and prolificacy in Raeini Cashmere goats. Trop. Anim. Health Prod., 44: 1213-1220.

Osman, M. A., 2013. Estimates of direct and maternal effects for early growth traits of Zaraibi goats. Egypt. J. Sheep and Goat Sci., 8: 7-14. $\left(4^{\text {th }}\right.$ Intern. Scientific Conference on Small Rum. Dev., 3-7 Sept., 2012, Sharm El Shiekh, Egypt).

Otuma, M.O. and I.I. Osakwe, 2008. Estimation of genetic parameters of growth traits in Nigeria Sahelian goats. Res. J. Anim. Sci., 2: 83-86. 
Paul, R.C. A. Rahman, S. Debnath, M. Khandoker, 2014. Evaluation of productive and reproductive performance of Black Bengal goat. Bang. J. Anim. Sci., 43: 104-111.

Rashidi, A., M. Sheikhahmadi, J. Rostamzadeh and J.N.B. Shrestha, 2008. Genetic and phenotypic parameter estimates of body weight at different ages and yearling fleece weight in Markhoz goats. Asian-Aus. J. Anim. Sci., 21: 1395-1403.

Ray, S., G. D. Nayak, S. K. Dhal, S.K. Mishra1, G. Sahoo, S. Mishra, S. K. Dash, 2015. Non-genetic effect on body weight and body measurements of Indigenous goats at different stages of growth in north central plateau climatic zone of Odisha, India. Explor. Anim. Med. Res., 5: 196-201.

Rout, P.K, O. Matika, R. Kaushik, G. Dass, M.K.Singh, M. D. Dige and S. Bhusan, 2018. Genetic analysis of growth parameters and survival potential of Jamunapari goats in semiarid tropics' Small Rum. Res., 165: 124-130.

Sadegh, Y.M., V.T. Rasoul, E.J.K. Naser and A. Mehdi, 2013. Estimation of genetic parameters for direct and maternal effects of growth traits in Iranian goats. Annals of Biological Research, 4: 20-26.

SAS, 2008. Statistics Analysis System user's Guide, (Release 9.2). SAS Institute Inc., Cary, North Carolina, USA.
Shaat, I., M. Mabrouk, A. Abdel-Raheem and A. Hamed, 2007. Estimates of heritability and correlations for milk and growth traits in Zaraibi goat. Egyptian J. Anim. Prod., 44: 161-171.

Snyman, M.A. 2012. Genetic analysis of body weight in South African Angora kids and young goats. S. Afr. J. Anim. Sci., 42: 146-155.

Supakorn, C. and W. Pralomkarn, 2009. Estimation of genetic and phenotypic parameters on preweaning growth traits in goats for meat raised at a commercial farm in southern Thailand. Thai. J. Agri. Sci., 42: 21-25.

Syahirah, M.Y., K.B. Mat, N.D. Rusli and C.H. Hasnita, 2016. Preliminary Study on Birth Weight and Pre-weaning Growth Pattern in Crossed Boer Kids. J. Trop. Resour. Sustain. Sci., 4: 6-9.

Willham, R.L., 1972. The role of maternal effects in animal breeding; III. Biometrical aspects of maternal effects in animal. J. Anim. Sci., 35, 1288-1293.

Zhang, C.Y., Y. Zhang, D. Q. Xu, X. Li, J. Su and L.G. Yang, 2009. Genetic and phenotypic parameter estimates for growth traits in Boer goat. Livestock Sci., 124: 66-71.

تقديرات مكونات التباين والمكافيء الوراثي لصفات النمو قبل الفطام للجديان الأنجلونوبيان والبلدي

محمد حسن حمود ، محمد محمود سالم

قسم الإتتاج الحيوانى والسمكي، كلية الزراعة، جامعة الإسكندرية

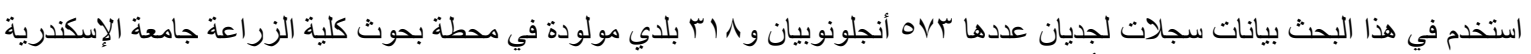

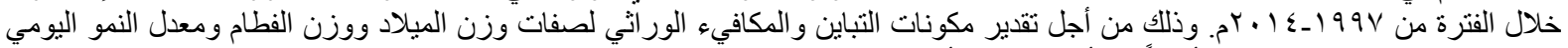

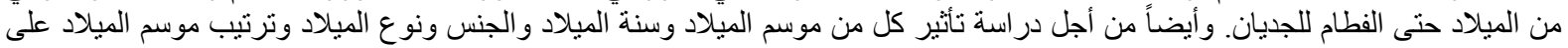

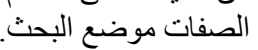

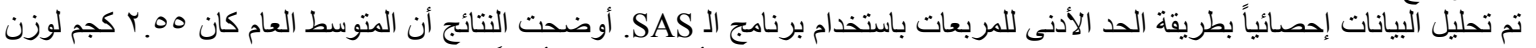

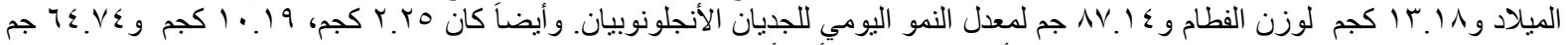

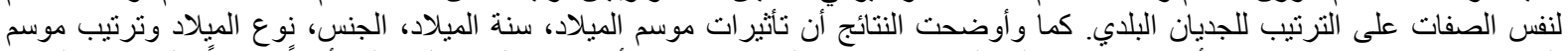

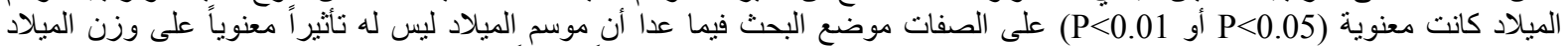

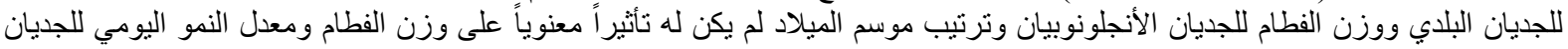

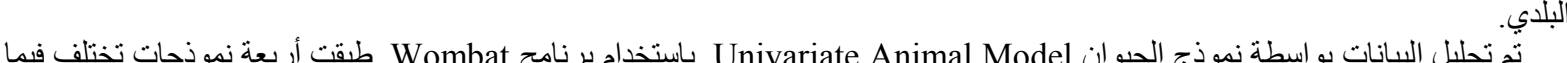

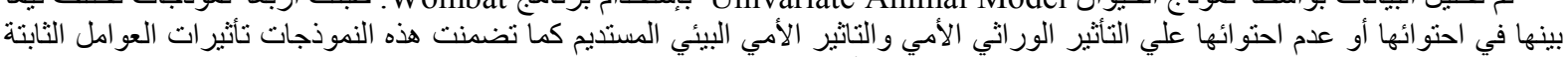

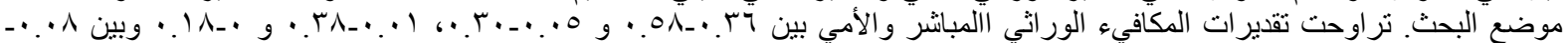

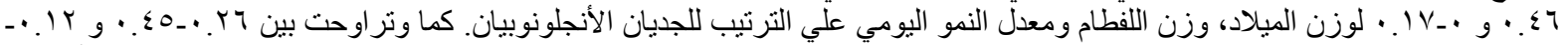

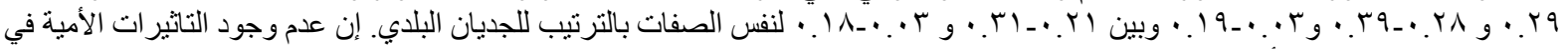

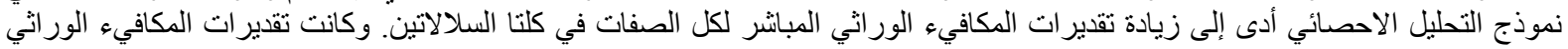

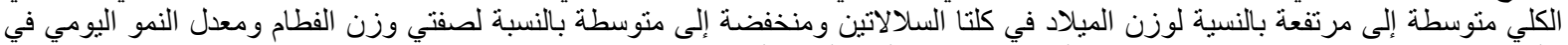

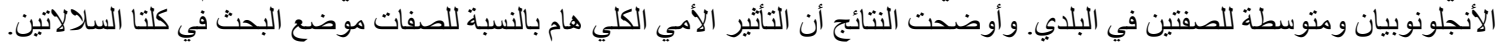

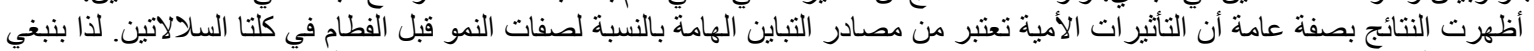

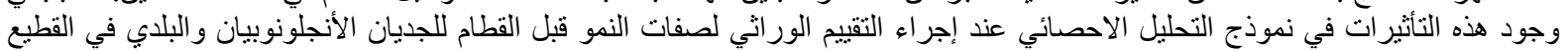
موضع البحث. 